\title{
INFLUENCE OF COLD-FORMED ANGLE ON HIGH STRENGTH STEEL MATERIAL PROPERTIES
}

\author{
Anh Tuan Tran ${ }^{1,}{ }^{*}$, Lars Bernspång ${ }^{1}$, Milan Veljkovic ${ }^{2}$, Carlos Rebelo ${ }^{3}$ and Luís Simões da Silva ${ }^{3}$ \\ ${ }^{1}$ Luleå University of Technology, Sweden \\ ${ }^{2}$ Delft University of Technology, The Netherlands \\ ${ }^{3}$ ISISE, University of Coimbra, Portugal \\ * (Corresponding author: E-mail: trananhtuangtvt@gmail.com)
}

\section{A B S T R A C T}

This paper describes a study of the $\mathrm{S} 650$ high strength steel material properties including the effect of cold -formed angle. Coupon specimens with different cold-formed angles $\left(90^{\circ}, 100^{\circ}, 120^{\circ}, 140^{\circ}, 160^{\circ}\right.$ and $\left.180^{\circ}\right)$ and different thicknesses $(4$ $\mathrm{mm}$ and $6 \mathrm{~mm}$ ) were examined. Relationships between cold-formed angle and yield stress as well as tensile stress of the $\mathrm{mm}$ and $6 \mathrm{~mm}$ ) were examined. Relationships between cold-formed angle and yield stress as well as tensile stress of the
material were determined, based on the tensile coupon test results. Yield and tensile stresses assessed by consid ering the influence of the cold-formed angles were compared with those without considering this influence. Analyses revealed that both yield and tensile stresses decreased with increasing cold-formed angle. Ductile-damage material models available in the finite element analysis software ABAQUS were used to simulate tensile coupon tests. The experimental and numerical results showed good agreements.

A R T I C L E H I S T O RY

$\begin{array}{ll}\text { Received: } & \text { 19 March } 2018 \\ \text { Revised: } & \text { 20 April } 2019 \\ \text { Accepted: } & \text { 05 May } 2019\end{array}$

\section{K E Y W O R D S}

High strength steel material

Cold-formed angle;

Tensile coupon test

Ductility;

Experimental investigation;

Finite element analysis;

Copyright $\odot 2019$ by The Hong Kong Institute of Steel Construction. All rights reserved.

\section{Introduction \\ Cold-formed steel members are used increasingly in industrial and civil} construction. Their use allows optimizing member cross sections and shapes, thereby reducing the amount of steel used as well as the weight of the structures and, consequently, reducing harmful effects on the environment. Cold-formed members are manufactured by either cold rolling method or press braking method. In the cold rolling method, the cold-formed member is obtained from passing flat steel sheet through a series of deformation stages. In the press braking method, the cold formed member is produced by bending a flat steel sheet along its length. The press braking method yields various cross sections and is therefore more popular than the cold rolling method.

Cold forming has significant effect on ductility and yield and tensile stresses of steel materials. In EN 1993-1-3 [1], influence of cold forming is considered by increasing average the yield stress of the whole cross-section. The average yield stress depends on the number of $90^{\circ}$ bends in the cross-section. Afshan et al. [2] determined the material properties of S355 carbon steel via tensile coupon tests. Flat coupon specimens, $90^{\circ}$ corner coupon specimens of the square hollow sections and rectangular hollow sections as well as circular coupon specimens of the circular hollow sections were investigated. The investigated cross sections had thicknesses of $5 \mathrm{~mm}$ and $6 \mathrm{~mm}$. The Ramberg - Osgood parameters from the tensile tests were also presented in the study. In a previous study [3], the properties of high strength steel were determined using tensile coupon tests. These tests were performed on corner coupon specimens and flat coupon specimens that were extracted from the hot finished and cold formed square hollow sections and rectangular hollow sections. The ratio of the yield stresses and tensile stresses of the corner and flat specimens were also determined. The stress-strain curves of flat and corner coupon specimens of S460, S500, and S690 materials also were compared. Ma et al. [4] investigated, via experiments, cold formed high strength steel materials with $0.2 \%$ offset yield stresses of $700 \mathrm{MPa}, 900 \mathrm{MPa}$, and $1100 \mathrm{MPa}$. A total of 66 tensile coupon tests was performed and various coupon specimens were considered, namely the: flat coupon, corner coupon, and curved coupon, which were extracted from the square hollow sections, rectangular hollow sections, and circular hollow sections. A new constitutive model, which uses the Ramberg - Osgood expression, was developed based on the experimental results. These results revealed that cold forming has significant effect on the material strength. In fact, the strength in the corner part of coupon specimens with $90^{\circ}$ bends, increased by up to $34 \%$ with effect of cold forming. Shi et al. [5] performed 46 tensile coupon tests on high strength steel materials that have nominal yield stresses of $500 \mathrm{MPa}, 550 \mathrm{MPa}$, and $690 \mathrm{MPa}$. The coupon specimens were grouped into two categories, namely those with thicknesses of (i) $<16 \mathrm{~mm}$ and (ii) $>16 \mathrm{~mm}$. Flat coupon specimens were tested at different load rates, different compliances, and different strain rates. The experimental results were used to develop a nonlinear constitutive model and a revised multi-linear constitutive model. Tran et al. [6] investigated the material strengths of the S650 high strength steel using 18 tensile coupon tests. The coupon specimens were extracted from the polygonal and circular cold-formed high strength steel sections.

This paper describes experimental and numerical studies of the S650 high strength steel material properties with effect of cold-formed angle using thirty tensile coupon tests. Tensile coupon specimens with different cold-formed angles $\left(90^{\circ}, 100^{\circ}, 120^{\circ}, 140^{\circ}, 160^{\circ}\right.$ and $\left.180^{\circ}\right)$ and different thicknesses $(4 \mathrm{~mm}$ and $6 \mathrm{~mm}$ ) were considered. Relationships between the cold-formed angles and yield stress as well as tensile stress of the material were investigated. The yield and tensile stresses determined by considering the influence of the cold-formed angle were compared with those determined without considering this influence. Ductile-damage material models in the commercial finite element analysis (FEA) programme ABAQUS [14] were used to simulate tensile coupon tests and then, the experimental and FEA results were compared.

\section{Experimental investigation}

\subsection{Coupon specimens}

In order to investigate the influence of cold-formed angles on the properties of high strength steel material, thirty coupon specimens with different cold-formed angles $\left(90^{\circ}, 100^{\circ}, 120^{\circ}, 140^{\circ}, 160^{\circ}\right.$ and $\left.180^{\circ}\right)$ and different thicknesses (4 mm and $6 \mathrm{~mm}$ ) were examined. Number and thicknesses of the coupon specimens were considered as limitation in this study. The coupon specimens were produced using a three-step process. In the first step, L-section profiles were produced from the high strength steel plates using the press braking method, Fig. 1.

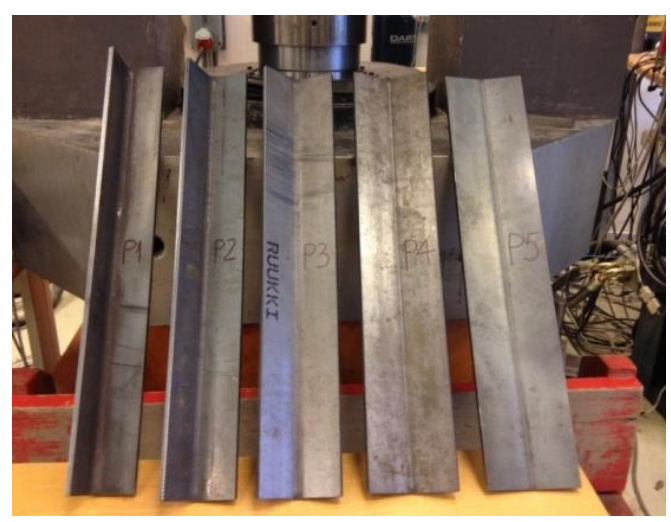

Fig. $1 \mathrm{~L}$ section profiles with different cold-formed angles 
In the second step, a water jet was used to cut the coupon specimens from the profiles with an extra $5 \mathrm{~mm}$ on each side to avoid any heating of the coupon specimens. In the last step, both sides of the coupon specimens were made perfectly perpendicular to the specimen surface and both ends of the specimens were then flattened to help clamping specimens during the tests, Fig. 2. Chen and Young [7] also flattened the ends of corner coupon specimens for tensile coupon tests to study the corner properties of cold-formed steel sections at elevated temperatures.

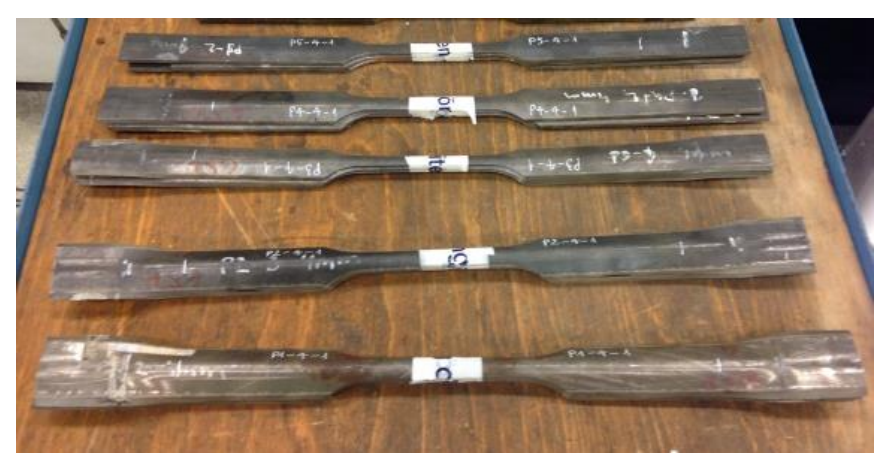

Fig. 2 Coupon specimens

Fig. 3 shows general dimensions of the tensile coupon specimen. Total lengths (Lt) of the specimens were approximately $596 \mathrm{~mm}$. The flattened part lengths (Lf) at both ends were used to help gripping the specimens during the tensile tests and were designed so that flattening does not affect the middle parts of the coupon specimens. The large radii (R2) were used to help failure sections occurred at middle of the specimens and were approximately 1513 $\mathrm{mm}$ and $2113 \mathrm{~mm}$ for the $4 \mathrm{~mm}$ and $6 \mathrm{~mm}$ thick coupon specimens, respectively.

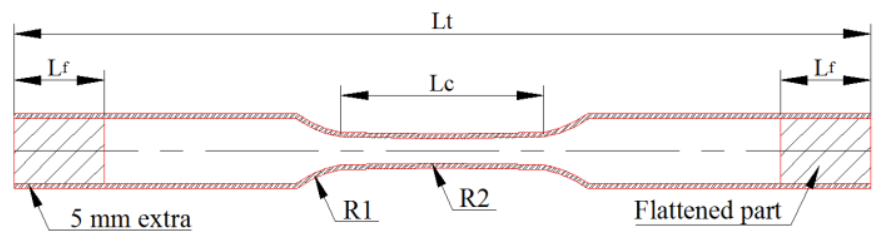

Fig. 3 General dimensions of the corner coupon specimen

Fig. 4 shows a typical cross section of the coupon specimens. Considered dimensions are inner radius (R3), outer radius (R4), width of the inner curves (B1), width of the outer curves (B2), and thickness (t). These dimensions were measured three times by using a digital caliper device with $0.01 \mathrm{~mm}$ of precision and used to define the area of the cross-section.

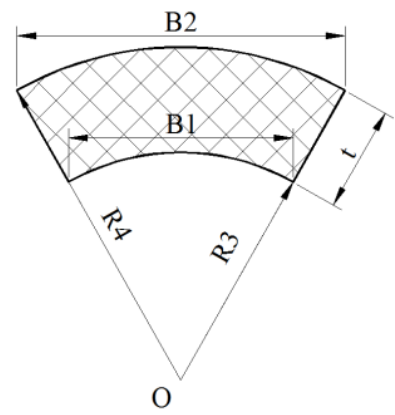

Fig. 4 Typical cross section of a corner coupon specimen

Tables 1 and Table 2 show the measured dimensions of cross sections of the 4 $\mathrm{mm}$ thick and $6 \mathrm{~mm}$ thick coupon specimens, respectively. The areas of the cross sections are also presented in these Tables. The following nomenclature are adopted for the specimens: angle of coupon specimen $\left\{\mathrm{C} 1\left(90^{\circ}\right), \mathrm{C} 2\left(100^{\circ}\right)\right.$, $\mathrm{C} 3\left(120^{\circ}\right), \mathrm{C} 4\left(140^{\circ}\right), \mathrm{C} 5\left(160^{\circ}\right)$ and $\left.\mathrm{F}\left(180^{\circ}\right)\right\}$ - thickness $\{4 \mathrm{~mm}$ and 6 $\mathrm{mm}\}$-test number in the test series $\{\mathrm{S} 1 ; \mathrm{S} 2 ; \mathrm{S} 3\}$.
Table 1

Dimensions of cross sections of the $4 \mathrm{~mm}$ thick coupon specimens

\begin{tabular}{|c|c|c|c|c|c|}
\hline Specimen & Angle & $\begin{array}{c}\text { B1 } \\
(\mathrm{mm})\end{array}$ & $\begin{array}{c}\mathrm{B} 2 \\
(\mathrm{~mm})\end{array}$ & $\begin{array}{c}\mathrm{t} \\
(\mathrm{mm})\end{array}$ & $\begin{array}{c}\mathrm{A} \\
\left(\mathrm{mm}^{2}\right)\end{array}$ \\
\hline C1-4-S1 & $90^{\circ}$ & 8.49 & 14.14 & 4.01 & 50.39 \\
\hline $\mathrm{C} 1-4-\mathrm{S} 2$ & $90^{\circ}$ & 8.40 & 14.22 & 4.01 & 50.36 \\
\hline C1-4-S3 & $90^{\circ}$ & 8.45 & 14.09 & 4.02 & 50.30 \\
\hline C2-4-S1 & $100^{\circ}$ & 7.69 & 12.82 & 4.02 & 44.74 \\
\hline $\mathrm{C} 2-4-\mathrm{S} 2$ & $100^{\circ}$ & 7.71 & 12.86 & 3.99 & 44.68 \\
\hline $\mathrm{C} 2-4-\mathrm{S} 3$ & $100^{\circ}$ & 7.66 & 12.91 & 4.00 & 44.68 \\
\hline C3-4-S1 & $120^{\circ}$ & 6.01 & 10.01 & 3.99 & 33.51 \\
\hline C3-4-S2 & $120^{\circ}$ & 6.05 & 10.03 & 3.96 & 33.37 \\
\hline C3-4-S3 & $120^{\circ}$ & 6.08 & 10.02 & 4.03 & 33.99 \\
\hline C4-4-S1 & $140^{\circ}$ & 11.62 & 14.36 & 4.00 & 55.34 \\
\hline $\mathrm{C} 4-4-\mathrm{S} 2$ & $140^{\circ}$ & 9.86 & 13.47 & 4.03 & 48.94 \\
\hline C4-4-S3 & $140^{\circ}$ & 7.10 & 9.58 & 4.01 & 34.63 \\
\hline F-4-S1 & $180^{\circ}$ & 10.90 & 10.90 & 4.10 & 44.60 \\
\hline $\mathrm{F}-4-\mathrm{S} 2$ & $180^{\circ}$ & 10.60 & 10.60 & 4.10 & 43.20 \\
\hline F-4-S3 & $180^{\circ}$ & 10.80 & 10.80 & 4.10 & 44.40 \\
\hline
\end{tabular}

Table 2

Dimensions of cross sections of the $6 \mathrm{~mm}$ thick coupon specimens

\begin{tabular}{|c|c|c|c|c|c|}
\hline Specimen & Angle & $\begin{array}{c}\text { B1 } \\
(\mathrm{mm})\end{array}$ & $\begin{array}{c}\text { B2 } \\
(\mathrm{mm})\end{array}$ & $\begin{array}{c}\mathrm{t} \\
(\mathrm{mm})\end{array}$ & $\begin{array}{c}\mathrm{A} \\
\left(\mathrm{mm}^{2}\right)\end{array}$ \\
\hline C1-6-S1 & $90^{\circ}$ & 12.73 & 21.21 & 6.00 & 113.10 \\
\hline C1-6-S2 & $90^{\circ}$ & 12.70 & 21.26 & 5.96 & 112.39 \\
\hline C1-6-S3 & $90^{\circ}$ & 12.71 & 21.18 & 6.02 & 113.23 \\
\hline $\mathrm{C} 2-6-\mathrm{S} 1$ & $100^{\circ}$ & 11.57 & 19.28 & 6.01 & 100.59 \\
\hline $\mathrm{C} 2-6-\mathrm{S} 2$ & $100^{\circ}$ & 11.62 & 19.31 & 6.03 & 101.31 \\
\hline $\mathrm{C} 2-6-\mathrm{S} 3$ & $100^{\circ}$ & 11.60 & 19.26 & 6.03 & 101.03 \\
\hline C3-6-S1 & $120^{\circ}$ & 9.02 & 15.01 & 6.02 & 75.75 \\
\hline C3-6-S2 & $120^{\circ}$ & 9.05 & 15.08 & 6.02 & 76.10 \\
\hline C3-6-S3 & $120^{\circ}$ & 9.00 & 15.01 & 6.00 & 75.41 \\
\hline C5-6-S1 & $160^{\circ}$ & 11.00 & 13.09 & 6.00 & 73.13 \\
\hline
\end{tabular}




\begin{tabular}{lccccc} 
C5-6-S2 & $160^{\circ}$ & 9.09 & 11.18 & 5.98 & 61.28 \\
C5-6-S3 & $160^{\circ}$ & 6.62 & 8.71 & 6.02 & 46.60 \\
F-6-S1 & $180^{\circ}$ & 11.10 & 11.10 & 6.01 & 66.7 \\
F-6-S2 & $180^{\circ}$ & 11.10 & 11.10 & 6.00 & 66.4 \\
& & & & & \\
F-6-S3 & $180^{\circ}$ & 11.00 & 11.00 & 6.01 & 66.1 \\
\hline
\end{tabular}

\subsection{Test set-up and instruments}

Dartec testing machine with maximum capacity of $250 \mathrm{kN}$ was used to perform the tensile coupon tests under laboratory temperature and humidity conditions. Displacements of the tensile coupon specimens during the tests were measured using an extensometer with $50 \mathrm{~mm}$ length gage allowing \pm 12.5 $\mathrm{mm}( \pm 25 \%)$ clearance in elongation. Fig. 5 illustrates the typical set up for the tensile coupon tests. The tensile coupon tests were carried out by displacement control method. EN 10002-1 [8] recommends rate limitations at crossheads for tensile coupon tests. For example, maximum and minimum stress rates of 6 $\mathrm{MPa} / \mathrm{s}$ and $60 \mathrm{MPa} / \mathrm{s}$, respectively, are recommended for testing within the elastic range and at stresses up to the yield stress. Maximum strain rates of $0.25 \%$ strain/s and $0.8 \%$ strain/s are recommended for testing within the plastic range at stresses up to the proof stress and greater than the proof stress, respectively. In this study, the tensile coupon tests were performed at a uniform crosshead displacement of $0.02 \mathrm{~mm} / \mathrm{s}$.

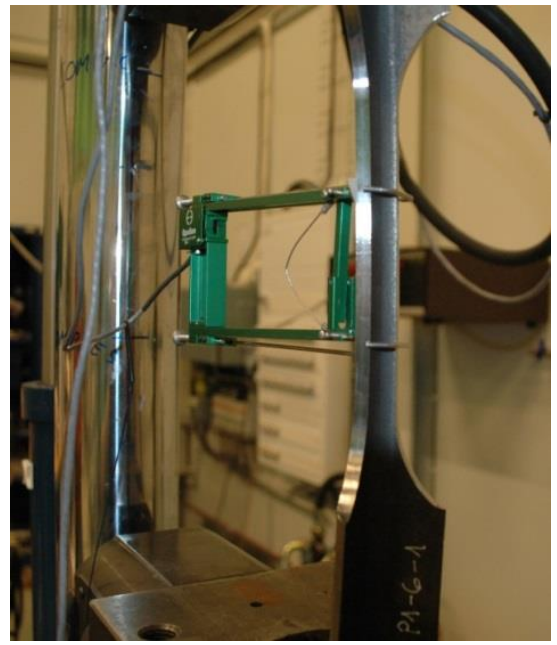

Fig. 5 Set-up for the tensile coupon test

\section{Experimental results}

Results of the tensile coupon tests are summarized in Table 3 to Table 5, which show the key parameters such as the yield stress $\sigma_{y}$, tensile stress $\sigma_{u}$, yield strain $\varepsilon_{y}$, tensile strain $\varepsilon_{u}$ and failure strain $\varepsilon_{f}$. Cold-formed angles of the coupon specimens are also presented in those tables. It should be noted that flat coupon specimens are named as $180^{\circ}$ cold-formed angles in this study. In some cases, the failure sections occurred outside the gauge lengths and, hence, those values (C1-4-S2, C4-4-S1 and C5-6-S1, C5-4-S1, S2, S3, C4-6-S1, S2, S3) were not recorded.

Cold-formed angle significantly affects material properties of the S650 high strength steel. Average tensile stress of the $4 \mathrm{~mm}$ thick coupon specimens with $90^{\circ}$ cold-formed angle is $7.7 \%$ higher than those of the specimens with $140^{\circ}$ cold-formed angles. Average tensile stress of the $6 \mathrm{~mm}$ thick coupon specimens decreases from $905 \mathrm{MPa}$ to $884 \mathrm{MPa}$ when cold-formed angles increase from $90^{\circ}$ to $160^{\circ}$. However, average strains at fracture significantly increase with increasing cold-formed angles. Average fracture strain of the 4 $\mathrm{mm}$ thick coupon specimens increases from $7.17 \%$ to $8.32 \%$ with increasing cold-formed angles (from $90^{\circ}$ to $140^{\circ}$ ). Average fracture strain of the $6 \mathrm{~mm}$ thick coupon specimens increases from $9.15 \%$ to $11.02 \%$ with increasing cold-formed angles (from $90^{\circ}$ to $160^{\circ}$ ). Results reveals the similar shape of the engineering stress-engineering strain curves of the $6 \mathrm{~mm}$ thick coupon specimens with different cold-formed angles $\left(90^{\circ}, 100^{\circ}\right.$, and $\left.160^{\circ}\right)$, Fig. 6 .
Table 3

Key material properties determined from the tensile coupon tests of the flat coupon specimens

\begin{tabular}{ccccccc}
\hline Specimen & Angle & $\begin{array}{c}\sigma_{y} \\
\left(\mathrm{~N} / \mathrm{mm}^{2}\right)\end{array}$ & $\begin{array}{c}\varepsilon_{y} \\
(\%)\end{array}$ & $\begin{array}{c}\sigma_{u} \\
\left(\mathrm{~N} / \mathrm{mm}^{2}\right)\end{array}$ & $\begin{array}{c}\varepsilon_{u} \\
(\%)\end{array}$ & $\begin{array}{c}\varepsilon_{f} \\
(\%)\end{array}$ \\
\hline F-4-S1 & $180^{\circ}$ & 762 & 0.60 & 802 & 10.6 & 19.2 \\
F-4-S2 & $180^{\circ}$ & 763 & 0.60 & 807 & 8.6 & 19.1 \\
F-4-S3 & $180^{\circ}$ & 762 & 0.60 & 806 & 8.5 & 19.0 \\
F-6-S1 & $180^{\circ}$ & 801 & 0.40 & 845 & 5.7 & 14.4 \\
F-6-S2 & $180^{\circ}$ & 793 & 0.40 & 843 & 6.0 & 14.8 \\
F-6-S3 & $180^{\circ}$ & 791 & 0.40 & 843 & 5.9 & 14.9 \\
\hline
\end{tabular}

Table 4

Key material properties determined from the tensile coupon tests of the $4 \mathrm{~mm}$ thick coupon specimens

\begin{tabular}{ccccccc}
\hline Specimen & Angle & $\sigma_{y}$ & $\varepsilon_{y}$ & $\sigma_{u}$ & $\varepsilon_{u}$ & $\varepsilon_{f}$ \\
\hline C1-4-S1 & $90^{\circ}$ & 889 & 0.62 & 929 & 1.18 & 7.24 \\
C1-4-S2 & $90^{\circ}$ & - & - & - & - & - \\
C1-4-S3 & $90^{\circ}$ & 925 & 0.64 & 951 & 1.24 & 7.09 \\
C2-4-S1 & $100^{\circ}$ & 932 & 0.64 & 948 & 1.02 & 7.06 \\
C2-4-S2 & $100^{\circ}$ & 927 & 0.64 & 948 & 1.12 & 6.98 \\
C2-4-S3 & $100^{\circ}$ & 914 & 0.64 & 944 & 1.16 & 7.36 \\
C3-4-S1 & $120^{\circ}$ & 837 & 0.60 & 895 & 1.25 & 7.34 \\
C3-4-S2 & $120^{\circ}$ & 865 & 0.61 & 917 & 1.17 & 7.04 \\
C3-4-S3 & $120^{\circ}$ & 859 & 0.61 & 898 & 1.15 & 6.97 \\
C4-4-S1 & $140^{\circ}$ & - & - & - & - & - \\
C4-4-S2 & $140^{\circ}$ & 839 & 0.60 & 876 & 1.51 & 8.97 \\
C4-4-S3 & $140^{\circ}$ & 831 & 0.60 & 859 & 1.07 & 7.66 \\
\hline
\end{tabular}

Table 5

Key material properties determined from the tensile coupon tests of the $6 \mathrm{~mm}$ thick coupon specimens

\begin{tabular}{ccccccc}
\hline Specimen & Angle & $\begin{array}{c}\sigma_{y} \\
\left(\mathrm{~N} / \mathrm{mm}^{2}\right)\end{array}$ & $\begin{array}{c}\varepsilon_{y} \\
(\%)\end{array}$ & $\begin{array}{c}\sigma_{u} \\
\left(\mathrm{~N} / \mathrm{mm}^{2}\right)\end{array}$ & $\begin{array}{c}\varepsilon_{u} \\
(\%)\end{array}$ & $\begin{array}{c}\varepsilon_{f} \\
(\%)\end{array}$ \\
\hline C1-6-S1 & $90^{\circ}$ & 782 & 0.57 & 896 & 1.50 & 9.39 \\
C1-6-S2 & $90^{\circ}$ & 830 & 0.60 & 923 & 1.46 & 8.85 \\
C1-6-S3 & $90^{\circ}$ & 874 & 0.62 & 896 & 1.22 & 9.20 \\
C2-6-S1 & $100^{\circ}$ & 843 & 0.60 & 898 & 1.37 & 9.48 \\
C2-6-S2 & $100^{\circ}$ & 861 & 0.61 & 893 & 1.31 & 9.69 \\
C2-6-S3 & $100^{\circ}$ & 853 & 0.61 & 890 & 1.37 & 9.41 \\
C3-6-S1 & $120^{\circ}$ & 878 & 0.62 & 916 & 1.33 & 10.31 \\
C3-6-S2 & $120^{\circ}$ & 883 & 0.62 & 917 & 1.32 & 10.41 \\
C3-6-S3 & $120^{\circ}$ & 845 & 0.60 & 905 & 1.69 & 10.88 \\
C5-6-S1 & $160^{\circ}$ & - & - & - & - & - \\
C5-6-S2 & $160^{\circ}$ & 778 & 0.57 & 867 & 1.67 & 11.52 \\
C5-6-S3 & $160^{\circ}$ & 826 & 0.59 & 881 & 1.34 & 10.52 \\
\hline
\end{tabular}




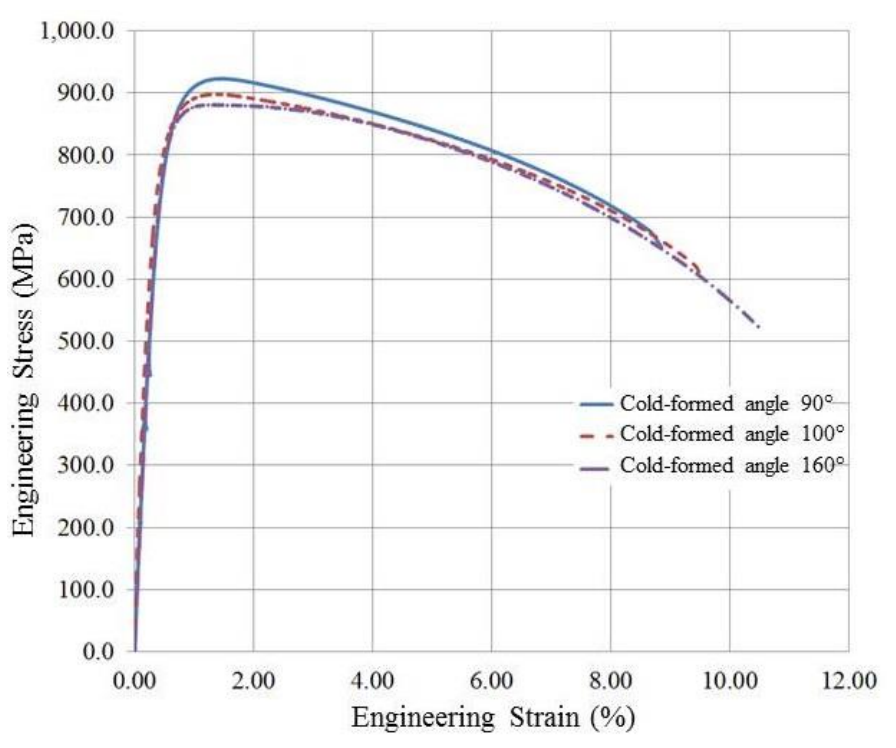

Fig. 6 Engineering stress-strain curves of the $6 \mathrm{~mm}$ thick coupon specimens with different cold-formed angles

\section{Proposed design rules}

\subsection{Influence of cold-formed angle on strength of material}

Figs. 7 and 8 show the relationship between cold-formed angle and the yield stresses and tensile stresses of the material S650. Tensile coupon test results performed by Wang et al. [13] for high strength steel materials S500 and S960 at the flat parts and corner $\left(90^{\circ}\right)$ parts are also shown in these figures. Trend lines are created based on the tensile coupon test results. The trend lines of different high strength materials S500, S650 and S960 show a similar trend of increasing yield stress and tensile stress as the effect of cold-formed angle increases. It should be noted that flat coupon specimen is named as $180^{\circ}$ cold-formed angle specimen. Based on the trend lines, the effects of cold-formed angle on yield and tensile stresses may be calculated using Eq. 1 and Eq. 2 respectively.

$\sigma_{y}=-1.258 \alpha+1007$

$\sigma_{u}=-1.085 \alpha+1027$

In these equations $\sigma_{y}, \sigma_{u}$, and $\alpha$ are yield stress, tensile stress and cold-formed angle respectively.

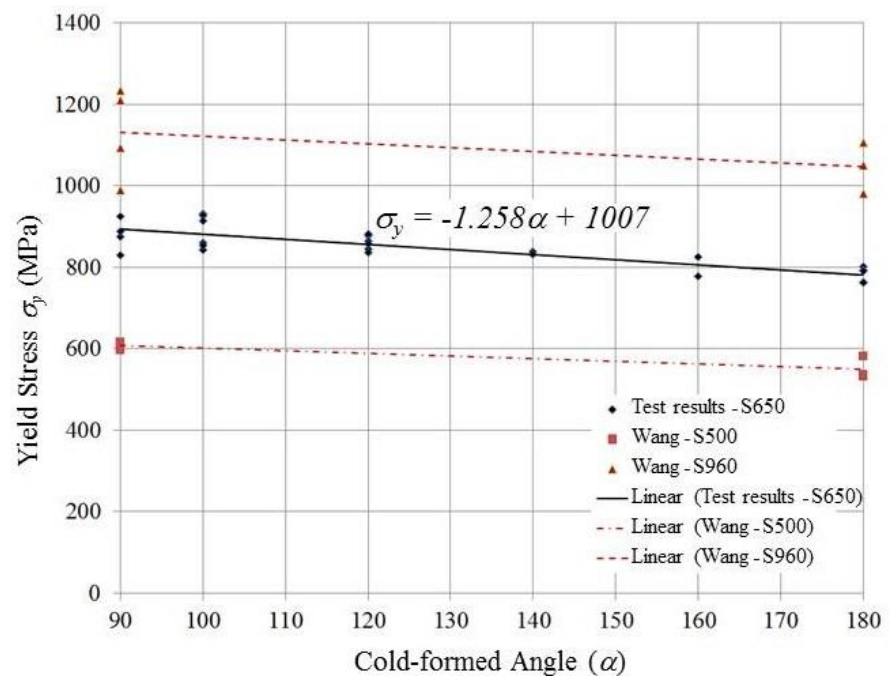

Fig. 7 Relationship between the yield stress and cold-formed angle

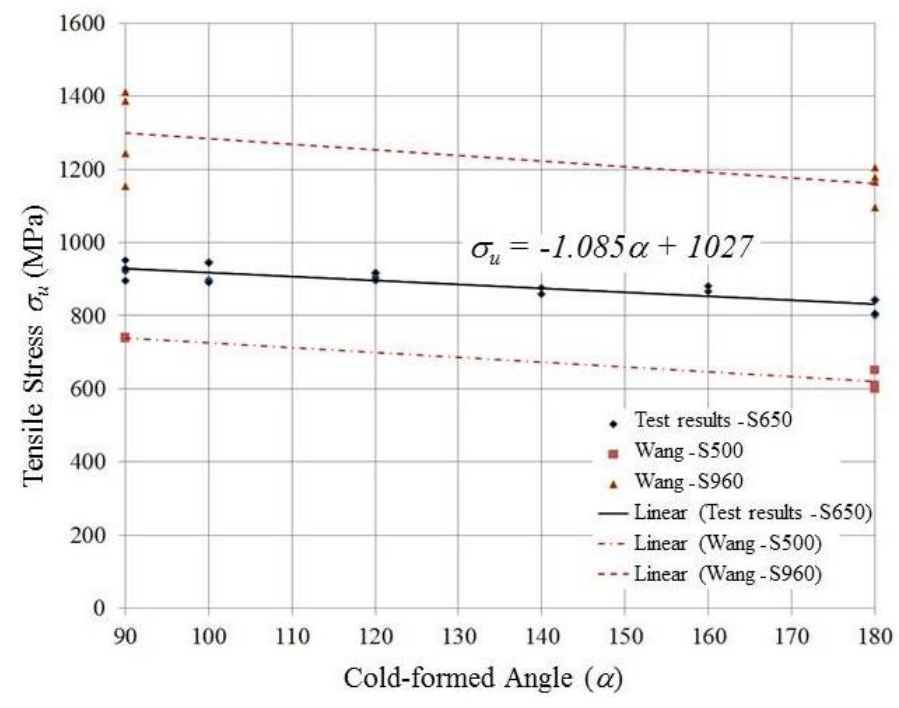

Fig. 8 Relationship between the tensile stress and cold-formed angle

In order to investigate effect of cold-formed angle on the original material strength, yield stress and tensile stress at corner parts of the tensile coupon specimens were compared to those at flat parts. Table 6 shows the ratios between yield stresses and between tensile stresses at the corner parts and the flat parts, as well as thicknesses and angles of the tensile coupon specimens. The comparisons show that cold-formed angle has significant effect on tensile and yield stresses of the S650 high strength steel material. Trend lines based on analyses are presented in Figs. 9 and 10. Relationship between yield and tensile stresses at corner parts and at flat parts of the tensile coupon specimens may be expressed as following function:

$\sigma_{\text {comer }}=\sigma_{\text {flat }}(-0.001 \alpha+1.2)$

Table 6

Stress comparison between the material with effects of cold-formed angle and its base material

\begin{tabular}{|c|c|c|c|c|}
\hline Specimen & Angle & $\begin{array}{c}\text { Thickness } \\
(\mathrm{mm})\end{array}$ & $\frac{\sigma_{y, \text { comer }}}{\sigma_{y, \text { flat }}}$ & $\frac{\sigma_{\mathrm{u}, \text { corner }}}{\sigma_{\mathrm{u}, \text { flat }}}$ \\
\hline C1-4-S1 & $90^{\circ}$ & 4 & 1.17 & 1.15 \\
\hline C1-4-S2 & $90^{\circ}$ & 4 & - & - \\
\hline C1-4-S3 & $90^{\circ}$ & 4 & 1.21 & 1.18 \\
\hline $\mathrm{C} 2-4-\mathrm{S} 1$ & $100^{\circ}$ & 4 & 1.22 & 1.18 \\
\hline $\mathrm{C} 2-4-\mathrm{S} 2$ & $100^{\circ}$ & 4 & 1.22 & 1.18 \\
\hline C2-4-S3 & $100^{\circ}$ & 4 & 1.20 & 1.17 \\
\hline C3-4-S1 & $120^{\circ}$ & 4 & 1.10 & 1.11 \\
\hline C3-4-S2 & $120^{\circ}$ & 4 & 1.13 & 1.14 \\
\hline C3-4-S3 & $120^{\circ}$ & 4 & 1.13 & 1.12 \\
\hline C4-4-S1 & $140^{\circ}$ & 4 & - & - \\
\hline $\mathrm{C} 4-4-\mathrm{S} 2$ & $140^{\circ}$ & 4 & 1.10 & 1.09 \\
\hline C4-4-S3 & $140^{\circ}$ & 4 & 1.09 & 1.07 \\
\hline C1-6-S1 & $90^{\circ}$ & 6 & 0.98 & 1.06 \\
\hline C1-6-S2 & $90^{\circ}$ & 6 & 1.04 & 1.09 \\
\hline
\end{tabular}




$\begin{array}{lcccc}\text { C1-6-S3 } & 90^{\circ} & 6 & 1.10 & 1.06 \\ \text { C2-6-S1 } & 100^{\circ} & 6 & 1.06 & 1.06 \\ \text { C2-6-S2 } & 100^{\circ} & 6 & 1.08 & 1.06 \\ \text { C2-6-S3 } & 100^{\circ} & 6 & 1.07 & 1.05 \\ \text { C3-6-S1 } & 120^{\circ} & 6 & 1.10 & 1.09 \\ \text { C3-6-S2 } & 120^{\circ} & 6 & 1.11 & 1.09 \\ \text { C3-6-S3 } & 120^{\circ} & 6 & 1.06 & 1.07 \\ \text { C5-6-S1 } & 160^{\circ} & 6 & - & - \\ \text { C5-6-S2 } & 160^{\circ} & 6 & 0.98 & 1.03 \\ \text { C5-6-S3 } & 160^{\circ} & 6 & 1.04 & 1.04\end{array}$

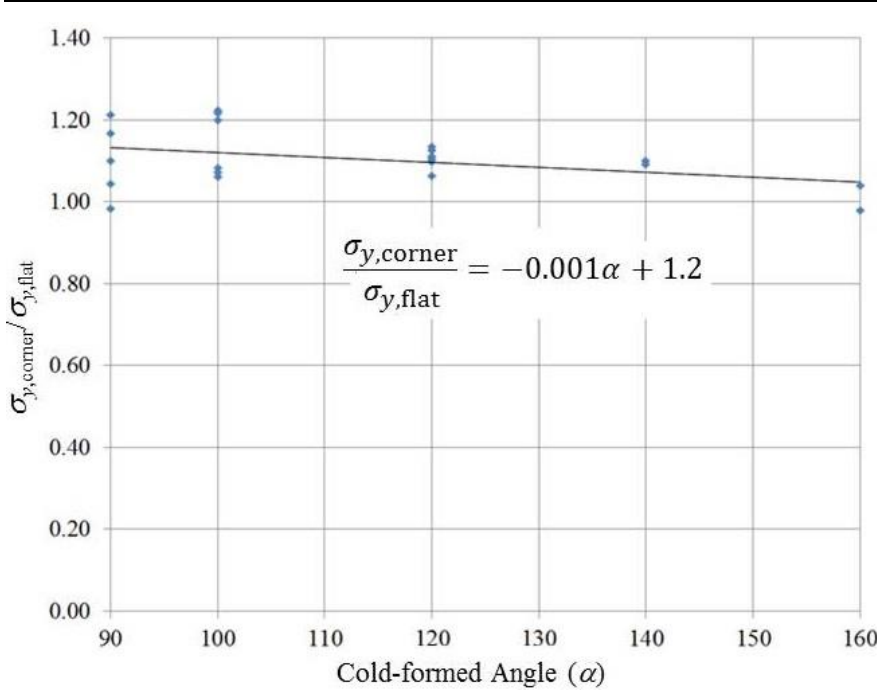

Fig. 9 Relationship between yield stress ratio and cold-formed angle

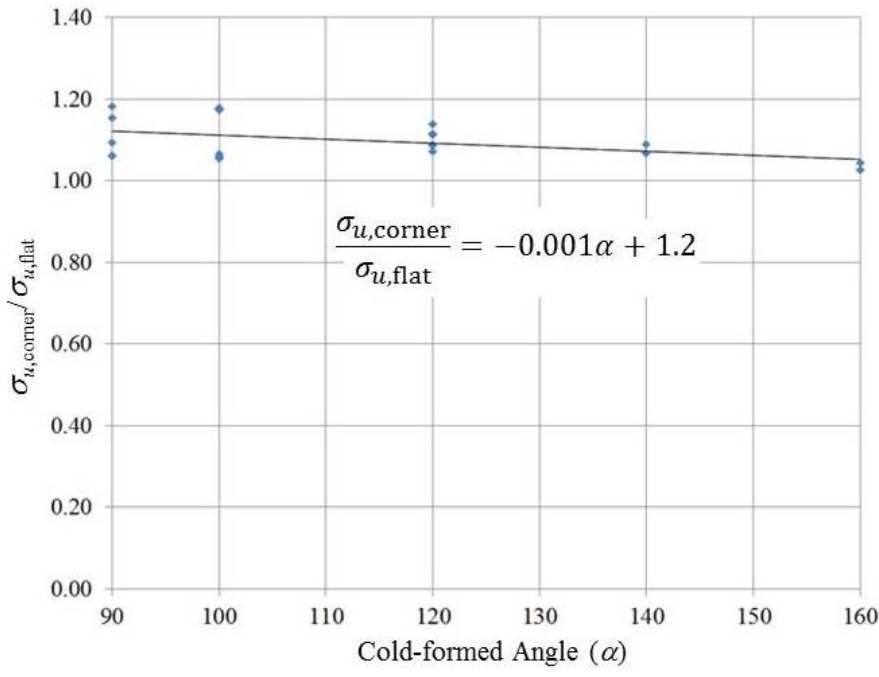

Fig. 10 Relationship between tensile stress ratios and cold-formed angles

\subsection{Influence of cold-formed angle on ductility of material}

According to EN 1993-1-12 [9], S460 to S700 steel materials should fulfil the following requirements $\sigma_{u} / \sigma_{v} \geq 1.05, \varepsilon_{u} \geq 15 \varepsilon_{v}$, elongation at failure: $\varepsilon_{f} \geq 10 \%$ where $\varepsilon_{u}$ and $\varepsilon_{y}$ are the tensile strain, and yield strain, respectively. ASTM-A514 [10] code specifies that high yield stress, quenched and tempered alloy steel plate, suitable for welding, must satisfy the following tensile and hardness requirements: at thicknesses of up to $65 \mathrm{~mm}$ (tensile stress: $760 \mathrm{MPa}-895 \mathrm{MPa}$, minimum yield stress measured at $0.2 \%$ offset: $690 \mathrm{MPa}$, minimum elongation: 18\%); at thicknesses $65 \mathrm{~mm}-150 \mathrm{~mm}$ (tensile stress: $690 \mathrm{MPa}-895 \mathrm{MPa}$, minimum yield stress measured at $0.2 \%$ offset: $620 \mathrm{MPa}$, minimum elongation: 16\%). ASTM-A709 [11] specifies four yield stress levels (250 MPa, $345 \mathrm{MPa}$, $485 \mathrm{MPa}$, and $690 \mathrm{MPa}$ ) for seven grades $(250,345,345 \mathrm{~S}, 345 \mathrm{~W}$, HPS $345 \mathrm{~W}$, HPS $485 \mathrm{~W}$, and HPS $690 \mathrm{~W})$ of structural steel designated for bridges. At plate thicknesses of up to $100 \mathrm{~mm}$, grades $250,345,345 \mathrm{~W}$, and $485 \mathrm{~W}$ exhibit minimum elongations of $23 \%, 21 \%$, $21 \%$, and $19 \%$, respectively. Moreover, for plate thicknesses smaller $65 \mathrm{~mm}$ and $65 \mathrm{~mm}-100 \mathrm{~mm}$, the $690 \mathrm{~W}$ grade exhibits minimum elongations of $18 \%$ and $16 \%$, respectively. It should be noted that the ductility requirements in the codes are applied to flat coupon specimens without considering the influence of cold forming.

Results of ductility analyses performed on the S650 high strength steel material, including influence of cold-formed angle, are presented in Fig. 11 to Fig. 13. The analyses show gathering of the results. It could prove quality of the coupon tensile tests. All results are outside of EN 1993-1-12 scope [9]. However, it emphasizes that the results are obtained with effects of cold-formed angle.

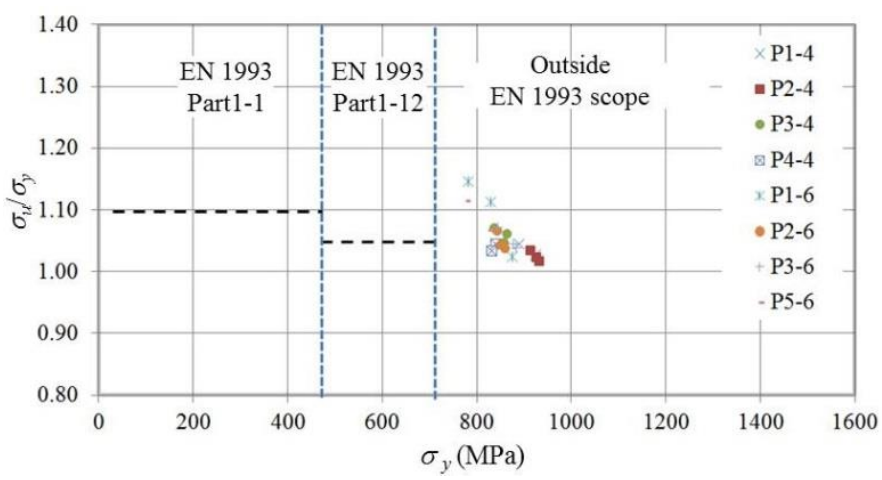

Fig. 11 Relationship between tensile stress and yield stress with effect of the cold-formed angles

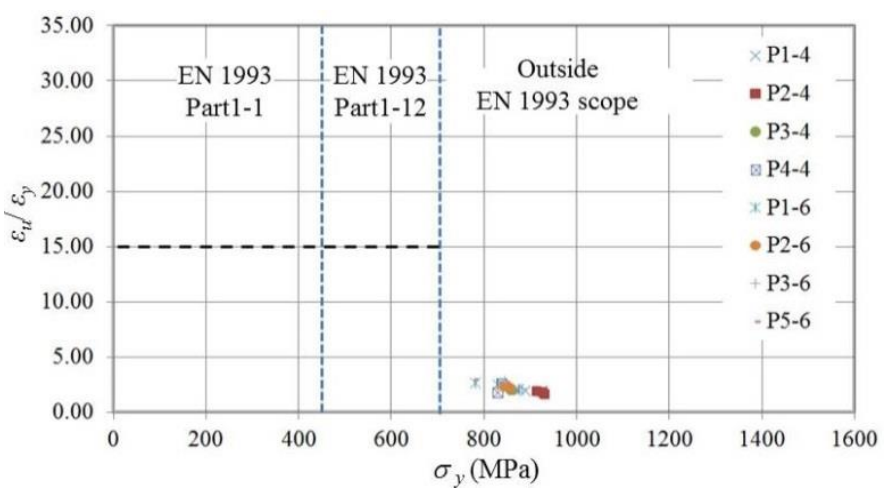

Fig. 12 Relationship between tensile strain and yield strain with effect of the cold-formed angles

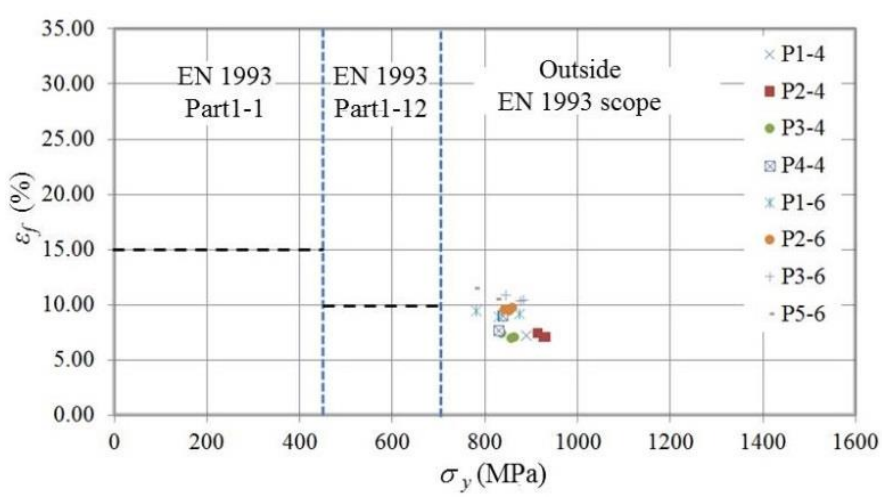

Fig. 13 Elongation at failure with effect of the cold-formed angles

Ductility factors were determined by statistical and $95 \%$ probability analyses. The corresponding probability density function (pdf) [12] is given as 
follows:

$f(x \mid \mu, \sigma)=\frac{1}{\sigma \sqrt{2 \pi}} e^{\frac{-(x-\mu)^{2}}{2 \sigma^{2}}} \quad, \quad-\infty<x<\infty$

Where $\sigma$ is a non-negative scalar value, $\mu$ is a scalar value. Fig. 14 to Fig. 16 present probability distributions of $\sigma_{u} / \sigma_{y}, \varepsilon_{u} / \varepsilon_{y}$ and $\varepsilon_{f}$ respectively. The probability distributions were determined based on the results of the tensile coupon tests. The $95 \%$ probability was used to determine ductility factors of the $\mathrm{S} 650$ high strength steel material including influence of cold-formed angle. The following ductility factors with effects of cold-formed angle are recommended:

- $\sigma_{u} / \sigma_{y} \geq 1.0$

- elongation of failure $\varepsilon_{f} \geq 6.3$

- $\varepsilon_{u} \geq 1.8 \varepsilon_{y}$

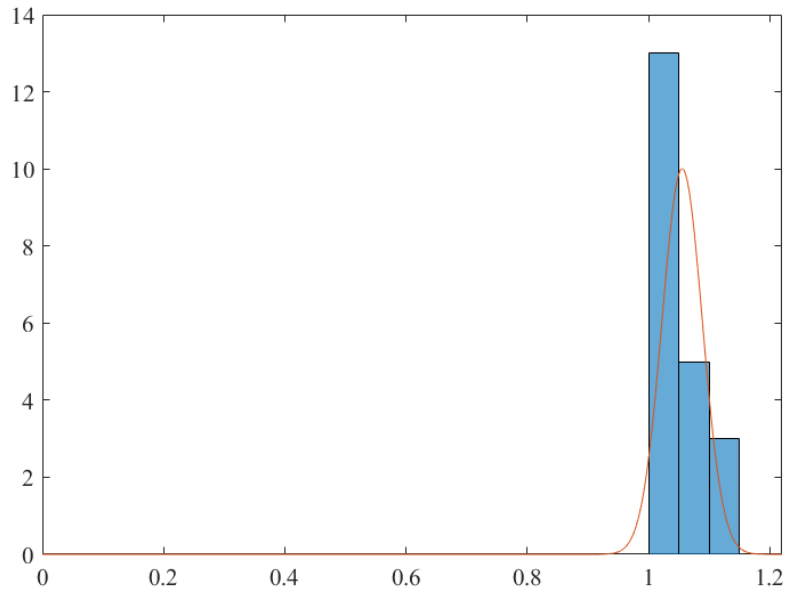

Fig. 14 Probability distribution of $\sigma_{u} / \sigma_{y}$

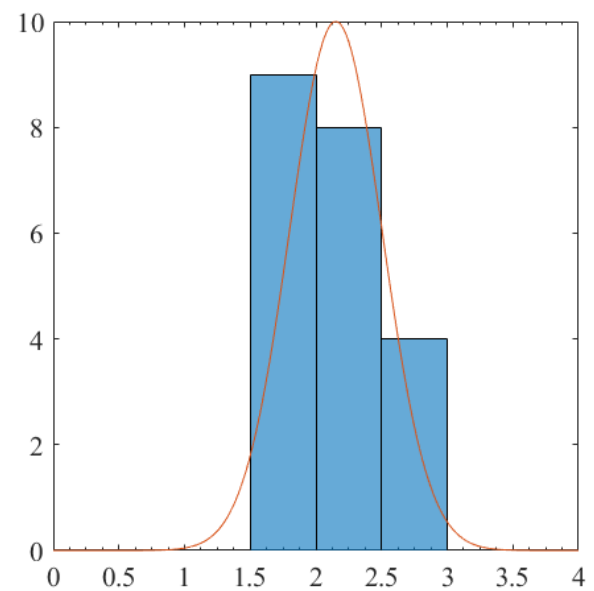

Fig. 15 Probability distribution of $\varepsilon_{u} / \varepsilon_{y}$

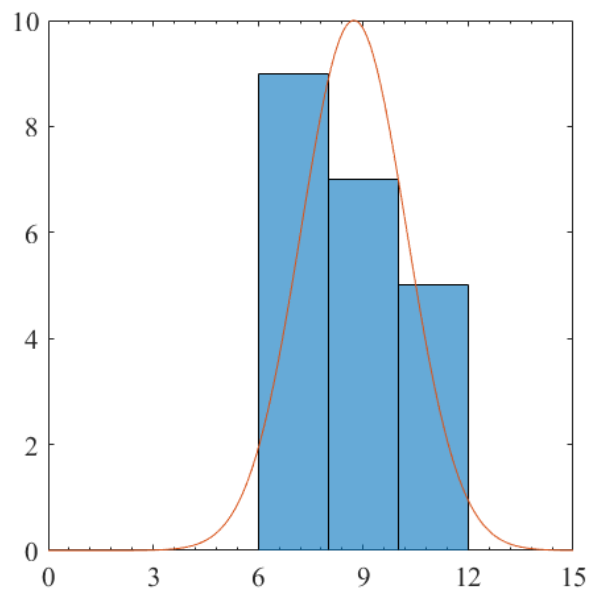

Fig. 16 Probability distribution of $\varepsilon_{f}$

\subsection{Ductile damage analysis}

In finite element analysis, the engineering stress $\left(\sigma_{\text {eng }}\right)$ and engineering strain $\left(\varepsilon_{e n g}\right)$ are converted to the true stress $\left(\sigma_{t r}\right)$, true strain $\left(\varepsilon_{t r}\right)$, and true plastic strain $\left(\varepsilon_{t r}^{p l}\right)$ by using following Equations

$\varepsilon_{t r}=\ln \left(1+\varepsilon_{\text {eng }}\right)$

$\sigma_{t r}=\sigma_{\text {eng }}\left(1+\varepsilon_{\text {eng }}\right)$

$\varepsilon_{t r}^{p l}=\varepsilon_{t r}-\frac{\sigma_{t r}}{E}$

In ABAQUS [15], Eq. 8 to Eq. 10 are used to define plastic curves based on the assumption that material is undamaged and exhibits perfect plastic behavior. Equations describing the onset of damage and damage evolution are used to create material curves where material damage is considered. The equivalent plastic strain at the onset of damage is defined as a function of the stress triaxiality and the strain rate, and is given as follows:

\section{$\bar{\varepsilon}_{D}^{p l}\left(\eta, \bar{\varepsilon}^{p l}\right)$}

Where $\eta$ and $\bar{\varepsilon}^{p l}$ are the stress triaxiality and the equivalent plastic strain rate, respectively. Overall damage variable is $\mathrm{D}=0$ at onset of damage and reaches $\mathrm{D}=1$ at failure point.

In this study, ductile damage material models were considered for $\mathrm{FE}$ analyses of the tensile coupon tests. Fig. 17 shows the meshes of the $6 \mathrm{~mm}$ coupon models with cold formed angles of $90^{\circ}, 100^{\circ}$, and $160^{\circ}$. Elements (size: $1.5 \mathrm{~mm}$ ) with 8-node linear brick and reduced integration with hourglass control (C3D8R) were used for these analyses. The computation time was reduced by considering only a half of the models. Furthermore, symmetry boundary conditions were applied.

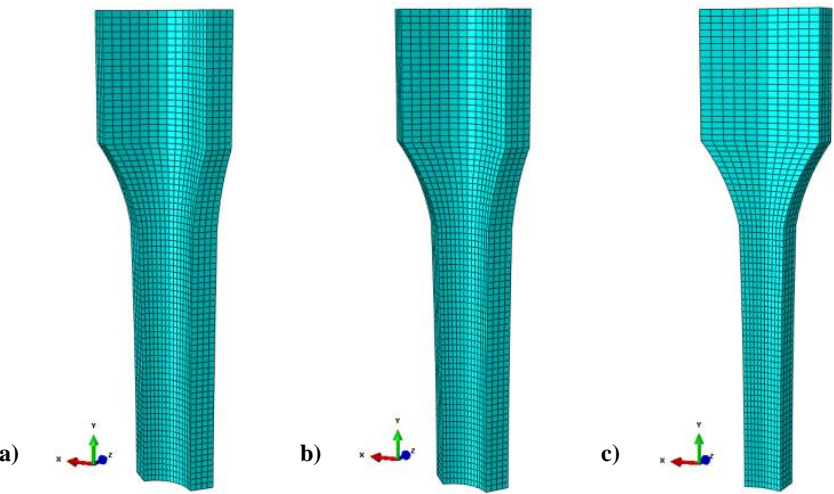

Fig. 17 Meshes of the coupon models with cold-formed angles of: a) $90^{\circ}$, b) $100^{\circ}$ and c) $160^{\circ}$ 
Fig. 18 shows the distribution of Von Mises stresses in the coupon models with cold-formed angles of $90^{\circ}, 100^{\circ}$, and $160^{\circ}$ at the rapture points. Cold-formed angle has significant effect on the stress distribution in the models. Considering the stress distributions at corner parts of the models, the stresses are spread farther along the length of the models and are closer to the end of the model with a $90^{\circ}$ cold-formed angle than in the model with $160^{\circ}$ cold-formed angle. At the rapture point, thicknesses of the models with $90^{\circ}$ and $160^{\circ}$ cold-formed angles are significantly reduced $35 \%$ and $38 \%$, respectively and their widths considerably decrease by $17 \%$ and $29 \%$, respectively.
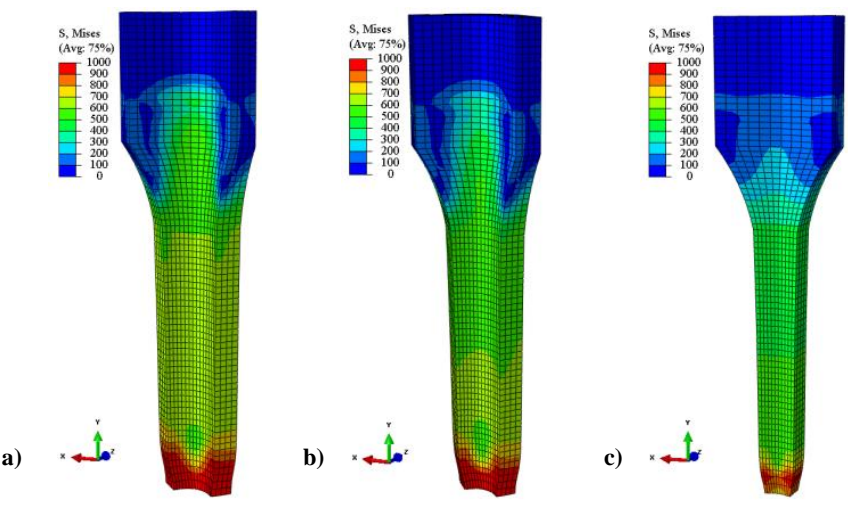

Fig. 18 Stress distribution in coupon models with cold-formed angles of: a) $90^{\circ}$, b) $100^{\circ}$ and c) $160^{\circ}$ at the rapture point

Fig. 19 and Fig. 20 reveal the good agreement between the experimental and FEA curves of the $6 \mathrm{~mm}$ thick coupon specimens with $100^{\circ}$ and $160^{\circ}$ cold-formed angles, respectively. At rapture point of the specimen with a cold formed angle of $100^{\circ}$, the stress and strain experimentally obtained differ by $1.8 \%$ from the respective FEA-determined values. Similarly, the stress and strain differ by $5.6 \%$ and $3.6 \%$, respectively, in the case of the specimen with $160^{\circ}$ cold-formed angle.

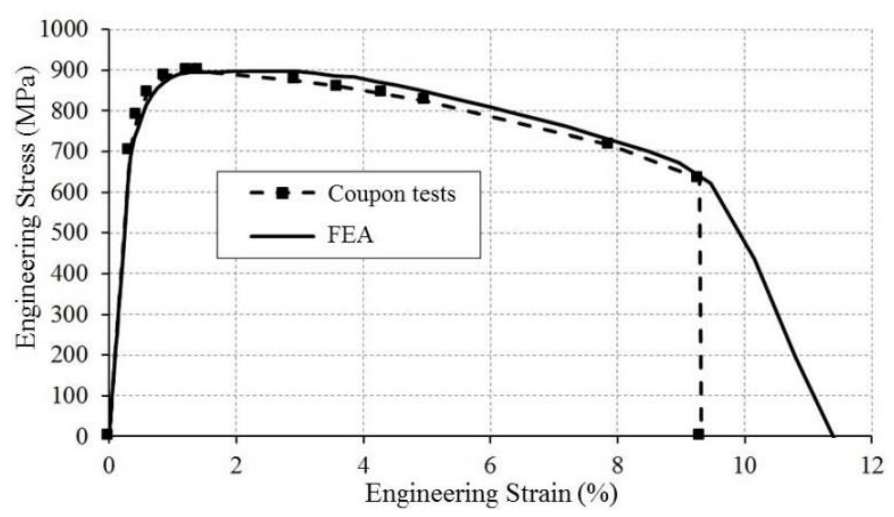

Fig. 19 Stress-strain curves obtained from the experiment and FEA of the $6 \mathrm{~mm}$ thick coupon specimen with $100^{\circ}$ cold-formed angle

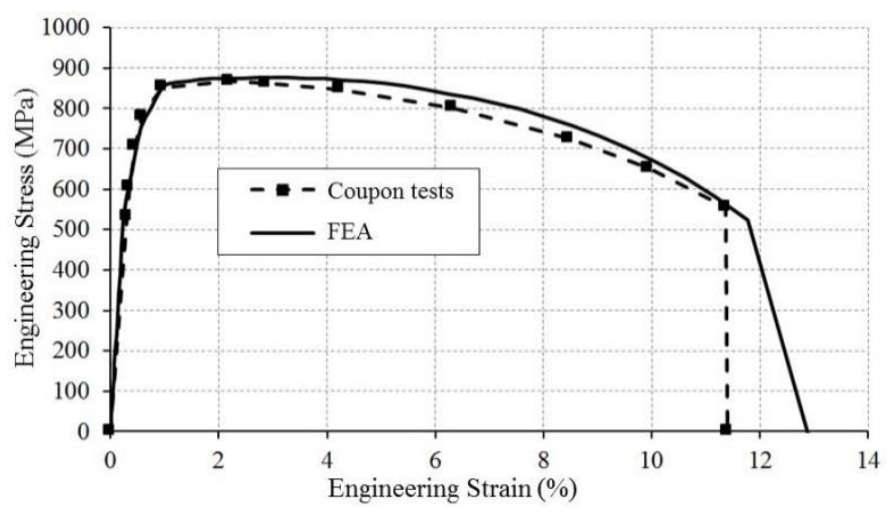

Fig. 20 Stress-strain curves obtained from the experimental and FEA of the $6 \mathrm{~mm}$ thick coupon specimen with $160^{\circ}$ cold-formed angle

\section{Conclusions}

The influence of cold-formed angle on properties of the S650 high strength steel material was assessed using tensile coupon tests and numerical simulations. Coupon specimens with different cold-formed angles $\left(90^{\circ}, 100^{\circ}\right.$, $120^{\circ}, 140^{\circ}, 160^{\circ}$ and $\left.180^{\circ}\right)$ and different thicknesses $(4 \mathrm{~mm}$ and $6 \mathrm{~mm})$ were tested. Based on the experimental and FEA results, following conclusions can be drawn:

The experimental results indicate that cold-formed angle has significant effect on properties of the S650 high strength steel material. The yield stress and tensile stress decrease by $9.4 \%$ and $10.3 \%$, respectively, with increasing (from $90^{\circ}-180^{\circ}$ ) cold-formed angles.

Based on the tensile coupon test results, relationships between the cold-formed angles and yield stress as well as tensile stress of the S650 high strength steel material are described in Eq. 1 and Eq. 2. Stress relationship between the material with effect of cold-formed angle and its base material is presented in Eq. 3.

It is clear from the results that cold-formed angle has considerable influence on ductility of the S650 high strength steel material. Ductility factors including the effect of cold-formed angle are recommended in Eq. 5 to Eq 7.

Ductile-damage material models in the ABAQUS software was used to simulate tensile coupon tests. The experimental and FEA results show good agreements. At the rapture point of the $6 \mathrm{~mm}$ coupon specimen with $100^{\circ}$ cold-formed angle, the experimentally determined stress and strain differ by $1.8 \%$ from the FEA results.

\section{Acknowledgements}

The authors wish to thank the Research Fund for Coal and Steel for financially supporting the research in this paper through the Research Project HISTWIN 2 (RFSR-CT-2010-00031).

\section{References}

[1] EN 1993-1-3, "Design of steel structures, Part 1-3: General rules - Supplementary rules for cold-formed members and sheeting", Brussels, Belgium: European Committee for Standardization, 2006.

[2] Afshan S., Rossi B. and Gardner L., "Strength enhancement in cold-formed structural sections - Part I: Material testing", Journal of Constructional Steel Research, 83, 177-188, 2013.

[3] Schillo N., Theofanous M., Gardner L. and Feldmann M. "Material properties and local buckling behavior of high strength steel hollow sections", Proceeding of 7th European conference on Steel and Composite Structures, Napoli, Italy, 10-12 September 2014.

[4] Ma J.L., Chan T.M. and Young, B., "Material properties and residual stresses of cold-formed high strength steel hollow sections", Journal of Constructional Steel Research, $109,152-165,2015$.

[5] Shi G., Zhu X. and Ban H., "Material properties and partial factors for resistance of high strength steels in China", Journal of Constructional Steel Research, 121, 65-79, 2016.

[6] Tran A.T., Veljkovic M., Rebelo C. and Simões da Silva L., "Resistance of cold-formed high strength steel circular and polygonal sections - Part 1: Experimental investigations", Journal of Constructional Steel Research, 120, 245-257, 2016.

[7] Chen J. and Young B., "Corner properties of cold-formed steel sections at elevated temperatures", Thin-Walled Structures, 44, 216-223, 2006.

[8] EN 10002-1, "Metallic materials - Tensile testing, Part 1: Method of test at ambient temperature", Brussels, Belgium: European Committee for Standardization, 2001.

[9] EN 1993-1-12, "Design of steel structures, Part 1-12: Additional rules for the extension of EN 1993 up to steel grades S700", Brussels, Belgium: European Committee for Standardization, 2007.

[10] ASTM-A514, "Standard specification for high-yield-strength, quenched and tempered alloy steel plate, suitable for welding", Am. Soc. Test Mater, 2013.

[11] ASTM-A709, "Standard specification for structural steel for bridges", Am Soc. Test Mater 2013.

[12] MATLAB R2015b, The MathWorks, Inc., Natick, Massachusetts, United States.

[13] Wang J., Afshan S., Schillo N., Theofanous M., Feldmann M. and Gardner, L., "Material properties and compressive local buckling response of high strength steel square and rectangular hollow sections", Engineering Structures, 130, 297-315, 2017.

[14] Abaqus 6.12-1, Simulia Dassault Systmes, 2012.

[15] Abaqus/Standard user's manual, Version 6.12. 